tened out from above downwards, but are still separate, and the lower-jaw arch, besides being divided into paletoquadrate and Meckel's cartilage, has approached still more nearly to the adult character by the conversion into fibrous tissue of its apex (Figs. 2 and $3, M \mathrm{Pt}$ ).

The third stage described was a ripe embryo, about two inches long, having nearly the form of the aduit. In this condition the external gills have entirely disappeared, the internal gills now performing the whole function of respiration. The skull has assumed all the characters of the adult, except as regards a few minor details, chondrification and segmentation being perfect. The investing mass has not only completely enclosed the notochord, but has formed an arch, like that of a vertebra, over the hinder part of the brain : in this way the occipital region of the skull is formed. The roof and walls of the brain-case, membranous in the last stage, have now become cartilaginous, and are fused with the nasal sacs in front, the trabeculæ below, and the auditory capsules and occipital region behind. The trabecula form the whole of the flat skull-floor in front of the ear capsules, where their original apices (pharyngo-trabeculars) are still to be seen as small rounded processes; they have completely coalesced behind, but are merely in apposition between the nasal sacs. The basi-trabecular (Fig. 2, B Tr) is small, and the first pair of labials $\left(1^{1}\right)$, which together with it form the "cutwater," are flat, and widely separated; the snout is consequently much blunter than in the adult. The hypo-trabeculars (cornua trabecule of Rathke) occur as two inturned $S$-shaped filaments of cartilage on either side of the basi-trabecular: no trace of them is to be found in the adult.

III.- Skull of the Ray or Thornback (Raia clavata).On the whole the skull of the ray resembles very closely that of the shark; in some respects, however, it approaches more nearly to the higher fishes, and in others, again, retains a lower or more embryonic character.

One of the chief points of difference between this type and the preceding is the nuch greater elongation of the skull, chiefly owing to the immense development of the basi-trabecular ( $\mathrm{Fig}$. 5, B Tr), which is produced to form the long, stout rostrum, the apex of which is strengthened by the first pair of labial cartilages $\left(1^{1}\right)$. The region between the orbits is much pinched in, while the nasal and auditory regions are extremely broad, the nose capsules, especially, being as far apart as in the embryo shark. On the upper surface, the prominences (epiotic, pterotic, sphenotic) already described in the shark, are seen; but instead of one, there are two fontanelles, an oval one between the nasal sacs, and a second of an oblong shape, in the more normal position, between the orbits. On the under surface of the nasal capsules are seen the second, third, and fourth labials, forming a valvular apparatus for the nostrils; the fifth labial and the extra-branchials are absent.

The upper and lower jaws or dentigerous arches closely resemble those of the shark; the opening of the mouth is, however more completely on the under surface of the head, as in the embryo Squaloid. In the front wall of the spiracle a semi-lunar cartilage $(\mathrm{M} \mathrm{Pt})$ is found, connected by ligament with the auditory capsule above, and with the angle of the lower jaw below, and having the same relations to the fifth and seventh nerves as the metapterygoid ligament of the shark (Fig. 2, M Pt), or the bone of the same name in the osseous fish; this, therefore, is the true apex of the mandibular or first postoral arch.

There is no mistaking the hyo-mandibular ( $\mathrm{H} \mathrm{M}$ ) a cartilage having precisely the same connection and relation to the hinder division of the portio dura as the part similarly named in the shark, but much more slender, pointed below, and inclined forwards. The remainder of the hyoid arch, however, has taken on an entirely new character, and shows a marked advance towards the Teleostian type, being at- tached, not to the lower part of the hyo-mandibular, but to its upper posterior angle, by means of a band of ligamentous fibre, answering to the small styliform bone (stylo-hyal of Cuvier) which in the osseous fish connects the free portion of the hyoid with the suspensory apparatus. The gill-bearing part of the hyoid is slenderer than in the shark, and more highly segmented, being divisible into epi- cerato-, and hypo-hyals ( $\mathrm{E} \mathrm{Hy}, \mathrm{C} \mathrm{Hy}$, $\mathrm{H} \mathrm{Hy)}$; the basi-hyal or keystone-piece is absent.

The branchial arches differ from those of the shark chiefly in the great development of the inferior segment or bypo-branchial. The first of these ( $\mathrm{H} \mathrm{Br}$. I) is much extended, and, uniting with its fellow of the opposite side, forms a transverse bar behind Meckel's cartilage. The second, third, and fourth hypo-branchials are broad adze-shaped plates, while the fifth is coalesced with its fellow in its hinder half, and extended forwards, so as nearly to meet the corresponding piece of the first arch.

The youngest ray described was an embryo of $R$. maculata, $I_{3}^{1}$ inch long; taken from the purse at about the seventh week from oviposition. The body proper is not larger than that of the first stage of the dog-fish, the greater length being due to the immense development of the tail. The pectoral fins, which by their expansion and union in front with the head, give to the adult ray its peculiar depressed form, are at this age small semielliptical lobes, one on each side of the umbilicus or point of attachment of the large yolk-sac. Six or seven long brarichial filaments, expanded or spatulate at the end, are attached to the hyoid and branchial arches, but none are apparent externally on the mandibular.

The facial arches are visible in a side view with perfect distinctness, and have already advanced considerably in segmentation, the apex of the mandibular being on the point of separation so as to form the spiracular cartilage, and the proximal end of the hyoid being cleft vertically, thus separating the hyo-mandibular from the epihyal.

Three months after oviposition, although the yolksac is still as large as a small walnut, the embryo has completely taken on the adult form, the pectoral fins having enlarged greatly, and brought the gill-slits to the ventral surface; from these the external branchia still project, being now in the form of long threads, almost like the hyphæ of a fungus; the first cleft behind the mouth (tympano-eustachian) remaining on the upper surface has taken on the form of the spiracular opening.

In the skull very few embryonic characteristics are left, the chief being that the brain-case is rounder, the rostrum shorter, and the two first labials separated from it by a slight interval, instead of being in perfect apposition.

\section{METEOROLOGY OF THE WEST INDIES}

$\mathrm{THE}$ kurricane season, here reckoned from July 25 to October 25 , went by without damage so far as the Windward and Virgin Islands are concerned, though not without disastrous examples of the phenomenon from which it derives its name elsewhere. Two cyclones of the ordinary kind have in fact visited these seas during the above period; and although neither of them included the island of St. Thomas in its range, yet they passed sufficiently near to make us aware of their existence, and to create considerable alarm among the inhabitants.

The first of these appears to have originated about lat. $10^{\circ} \mathrm{N}$. long. $55^{\circ} \mathrm{W}$., on or near August 10. Taking a northwesterly direction it passed parallel with, but at a considerable distance from the Windward islands, where from August II to 13 the weather showed signs of great disturbance with violent squalls, that shifted to every part of the compass; while at Martinique in particular, where 
the most threatening signs appeared, the mercurial barometer sank to $29^{\circ} 60$. On the 14 th similar indications showed themselves at St. Thomas-rain, squalls, and thunder; while on the night of the 15 th the barometer suddenly fell to $29^{\circ} 70$, and a violent gust of wind from the north caused many of the natives to barricade their windows in anticipation of the worst. This state of things lasted till next day at noon, when the mercury rose and the sky cleared.

But by this time the cyclone, now only about a hundred miles to the east of the islands, had fully formed itself ; and henceforth its course was only too clearly marked by the damage it caused among the shipping. From August 17 to 24 it passed north, with a westerly inclination, till it fell in with the course of the Gulf Stream, above Florida, and then followed that line, but gradually nearing the coast, up to Nova Scotia, where the ravage was tremendous, upwards of a hundred vessels having been either dismasted, or rendered total wrecks. Further north the cyclone seems to have expanded into an ordinary storm and disappeared.

These particulars I gathered from the captains of the injured vessels, some of which took refuge in this port. They are illiterate men, and not capable of furnishing exact details; but all agreed in describing the wind-current as having been from north to south by west, and so back by east to north; the lowest barometric indication I heard speak of was $29^{\circ}$.

The second cyclone originated in the Carribæan Sea itself, to the west of Barbadoes. Telegrams of threatening weather dated September 25 reached us at St. Thomas; and on the 26 th the aspect of matters here was gloomy; the sky murky, especially to the south, with continued flashes of lightning, and a very heavy sea. But the hurricane did not touch Santa Cruz; its first long-shore visit having been made on the 28 th at Haiti, where several small ships were lost, and much mischief done. Jamaica escaped; but on the 3 oth the whole southern coast of Cuba was ravaged from east to west, and many lives lost by sea and shore. From Cuba the cyclone continued to pass west till it reached the Mexican coast, which it skirted, then turned east, touching Havanna on October 4, Florida on the $7: h$, and then, following the Gulf Stream, was lost in mid-ocean. Its greatest fury was in the Gulf of Mexico itself, where the injury done to the shipping almost equalled that caused off Halifax by the gale of August 24 .

Some disquietude has also been caused here at St. Thomas by the frequency of slight earthquake shocks, of which I counted five within a period of forty days. The two strongest occurred on July 22 and August 12 ; in both instances the movement appeared to pass from east to west; it was accompanied by a distinct rumbling sound. The shock of August 12 occurred at 8.15 P.M., and was within a few seconds followed by another, but slighter. In two instances, June 16 and August 27, a slight shock at this island had been preceded, about an hour and a half before, by a stronger one at Jamaica : so that the general direction of the movement must have been contrary to the apparent surface vibration from west to east.

I may add that the whole of this island is manifestly undergoing a gradual upbeaval, as appears by the waveworn rocks of recent date, but already two or three feet above water mark; sea-shells and corals left dry, and similar indications. Hence the artificial channel cpened, for purposes of cleansing by means of the current thus established, between the south-western extremity of the harbour and the outer sea, and which is in itself a clean cut, twenty feet wide, through a narrow band of rock, has, since 1870 , when it first was made, lost so much of its depth as scarcely to allow of boat-passage ; and threatens at no distant period to become absolutely useless.

W. G. Palgrave

\section{NOTES}

霞 The well-known German serial, Poggendorff's Annalen der Physik und Chemie has now been in existence fifty years, and we are glad to see that practical recognition has just been taken of the striking fact that it has, during this long period, been under the sole editorial direction of Prof. Poggendorff, while printed and published by the same house in Leipzic. It was agreed, a short time since, by a number of friends of the learned professor, that they should relieve him of his editorial duties for one volume, and that this should be presented to him in honour of the occasion, as a "Jubelband," or Jubilee volume. The importance of the work done by M. Poggendorff and his collaborateurs, during half a century, through the Annalen, is sufficiently obvious to any who have taken an interest in the progress of physical science in recent years. The serial well reflects that enterprise, plodding in. dustry, and philosophical insight, which mark original research in Germany; and the 156 volumes that have appeared (six of these supplementary) constitute an invaluable storehouse for any one desiring to prosecute new lines of investigation in the wide field of physics. We learn from the preface to the Jubilee volume (which we hope to notice at greater length) that the entire number of papers published in the Annalen hitherto is $8,85^{\circ}$; and among the 2,167 authors who have contributed to its pages, we find the eminent names of Liebig, Magnus, Berzelius, Rammelsberg, Rose, Faraday, Brewster, Becquerel, Regnault, and many others. A work of this kind, as is truly remarked, unites those engaged in similar researches all over the world, into one large brotherhood of mutual assist. ance and regard. We congratulate the learned editor on the completiou of such a long term of arduous and honourable service to Science, and heartily join in the wish that this Jubilee volume may be followed by "many others edited by the "Jubilar" himself.

WE are given to understand that preliminary negotiations are on foot for the establishment of a central establishment for Ocean Meteorology in Germany. We may hope that when such a step is in contemplation, the work done by Herr von Freeden, who has for the last seven years conducted the Norddeutsche, lately called the Deutsche Seewarte, at Hamburg, will meet with its full measure of recognition. The establishment in question has been maintained at the sole expense of the town of Hamburg, and has risen steadily from a small beginning to its present state of thorough efficiency, thanks, in great measure, to the energy of its director.

IN the review of Belt's "Naturalist in Nicaragua" by Mr. Wallace, p. 221, reference is made to the theory of the origin of cyclones propounded by the author in terms which might lead our readers to think that his views have been entirely unnoticed. Such is however not the case, and our attention has been drawn to Prof. Reye's work " Die Wirbelstiirme, \&c., in der ErdAtmosphäre, mit Berüicksichtigung der Stïrme in der SonnenAtmosphäre" (Hanover 1872 ), in which Mr. Belt's views are discussed at some length, with an expression of regret that so little attention has been attracted to them.

The 'Turners' Company of the City of London have acknow. ledged the debt which their Art owes to pure scientific research, by presenting the freedom and livery of that Company to Dr. John Phillips, F.R.S., Professor of Geology in the University of Oxford, in recognition of his introduction into architecture of the various materials which constitute the rocks of England. Mr. John Jones, a member of the livery, said the City of London was always willing to bestow its honours on successful generals, conspicuous statesmen, and devoted patriots -and the tributes were honourable to both sides-but that was the very first ccrasion on which they had offered 